\title{
AUTORZY POGAŃSCY O CHRZEŚCIJAŃSTWIE (Galen, Ammianus Marcellinus)
}

Wystarczy z grubsza przejrzeć pierwszy lepszy podręcznik akademicki historii Kościoła w starożytności, aby się przekonać, że ich autorzy chętnie odwołują się do świadectw pisarzy pogańskich o chrześcijaństwie i to niezależnie od tego, czy te świadectwa są pochlebne, czy krytyczne. Jest to zabieg ze wszech miar słuszny, albowiem zyskuje się w ten sposób przesłanki do bardziej obiektywnej oceny tego nowego historycznego zjawiska, któremu na imię chrześcijaństwo.

o jakie dokumenty tu chodzi? Przede wszystkim o urzędowe edykty, $\cdots$ reskrypty, czy innego charakteru rozporządzenia cesarskie o prześladowaniach, dalej o opinie kół intelektualnych greckich 1 rzymskich, a więc filozofów, historyków, a nawet poetów, wreszcie o tzw. libelli sacrificationis, tj. urzędowe zaświadczenia państwowej komisji o złożeniu przez chrześcijan ofiary bogom, nakazanej przez Decjusza. Spośród tych dokumentów szczególne znaczenie mają te, które saz źródłami jedynymi w danej sprawie. Przykładów na to można przytoczyć wiele, ale niech wystarczy jeden: wszystko, co wiemy o pochodniach Nerona 1 męczennikach watykańskich zawdzięczamy jednemu tylko Tacytowi ${ }^{1}$. W kilku zaś przypadkach dokumenty pogańskie oświetlają ze swego punktu widzenia wydarzenia znane nam ze źródeł chrześcijańskich /np. Ammian Marcellin o wyborze Damazego/, albo też potwierdzają ze swej strony 1 w sobie właściwy sposób informacje pisarzy chrześcijańskich /np. libelli sacrificationis a "De lapsis" Cypriana/. Sledząc wypowiedzi pogan o Chrystusie, a przede wszystkim o chrześc1jaństwie, widzimy jak na dłoni trudności, z jakimi musieli się borykać niektórzy poganie na swojej drodze ku chrześcijaństwu, bo propaganda pogańska przedstawiała je w najciemniejszych barwach 1 w najgorszym świetle. Trzeba było wiele hartu ducha i nieraz ogromnego wysiłku umysłowego, aby w zalewie oszczerstw, posądzeń, pomówień

1 Por. Annales XV 44. 
w atmosferze kpin 1 szyderstw dojść do prawdy chrześcijańskiej. Większość dochodziła do niej na drodze prowadzonej przez Koścí́ ewangelizacji, inni zaś szukali jej u przyjacióz chrześcijan 1 dzięki tej przyjacielskiej korespondencji mamy takie dzieła, jak uroczy "List do Diogneta" lub trzy ksiegi Teofila "Do Autolika", Inni znów nawracali się pod wpływem lektury Pisma św., czego wymownym przykładem jest Tacjan, a wreszcie inni w przyjacielskiej rozmowie, jak np. Justyn. Ataki polemiczne na chrześcijaństwo, oczernianie go 1 zniesławianie, choć niewątpliwie przynosiły szkody, miały jednakże 1 tę dobrą stronę, ze wiejednym przypadku pobudzały atakowanych do obrony, wyniku czego powstawały tak wspaniałe apologie, jak "Contra Celsum" Orygenesa.

Kiedy zbierze sie wypowledzi pogan o chrzescijanstwie 1 zestawi sie je obok siebie, nietrudno dojść do wniosku, ze najostrzejsze ataki na chrześcijaństwo 1 jego naukę wyszły z kręgów filozopil /Celsus, Porfiriusz/, a bardziej obiektywni okazali sie historycy /Tacyt, Ammian Marcellin/ 1 lekarze/Galen/. Ten ostatni wydaz chlubne świadectwo o moralności chrześcijan II wieku. Od końca IV wieku pojawiają się świadectwa pogan o będącym wówczas w rozkwicie zyciu zakonnym. Wiadomości, jakie o nim docierały do uszu pogan były wręcz karykaturalne, totez $1 \mathrm{ch}$ wypowiedzi sq pełne wagardy 1 nienawíci. Dla retora Libaniosa sa to "ludzie w czarne szaty ubran1, zarłoczniejsi od słoni", oddani pijatykom 1 napadający na świątynie pocańskie ${ }^{2}$. Nie mniejszą odrazę do mnich 6 w czuł łaciński poeta IV w. Rutiliusz Namatian, kiedy wracajz̨c z Rzymu do Gali1, aby ratować swe posiadłośc1 zagrozone wędrówką б́czesnych ludów, przepływał obok wyspy Kaprarii, "wiało od niej - jak powiada - nieprzyjemnie, bo pełna jest męźów unikających światła, co sami siebie nazywaja z grecka monachami, ponieważ chcą zyć samotnie /.../ lękają się darów fortuny $/ \ldots /$, głupi szał przewrotnego umys $¥ u^{\prime \prime}{ }^{3}$. A juz jadem fanatycznej nienawiści zioną słowa, a raczej złorzeczenia sofisty z 2. poł. IV w. Eunapiosa: "Z wyglądu są to ludzie, zyją jednak jak

2 Orat1o XXX 164-165, ed. Foerster, III, 91, tłum. L.Małunowiczówna /L1banios, Wybór mów, Wrocław 1953/, 231.

3 De reditu suo I $439-452$. 
wieprze, w sposób jawny pozwalając czynić i sami czyniąc mnóstwo rzeczy podłych $i$ wręcz nie do opowiedzenia" ${ }^{4}$. Z wygasaniem pogaństwa zanikały również takio pogańskie głosy. Z V wieku niewiele ich już mamy /Eunapios, Rutilius Namatianus, Zosimos/, z wieku zaś VI doszedł do nas jedyny zapewne głos ostatniego kierownika Akademi platońskiej w Atenach, neoplatonika Damaskiosa /+ ok. 553/. Osobistą tragedią tego ostatniego czciciela starych bogów było zamknięcie przez cesarza Justyniana wspomnianej Akademii w $529 \mathrm{r}^{5}$. Próby jej wskrzeszenia w Persji nie dały rezultatów, toteż Damaskios wrócił na teren cesarstwa $i$ oddał się wyłącznie pracy literackiej, której owocem było m.in. "Życie Izydora", jegomistrza i "Paradoksy", tj. księgi o dziwach, demonach, duchach pojawiających się po śmierci itp. Obydwa te dzieła napisał w duchu swojej szkoły, a szkoła ta "w przeciwieństwie do szkoły aleksandryjskiej twardo sprzeciwiała się jakiemukolwiek porozumieniu z chrześcijaństwem. W tej dyskretnie, ale zapamiętale prowadzonej walce, brali czynny udzial kierownicy szkoły: Syrian /od $431 \mathrm{r} . /$, Proklos /do 485/ i Damaskios /do $529 / " 6$. Damaskios, patrząc na zgon istniejącej 900 lat Akademii/założonej przez Platona ok. 385 r. przed Chr./, a równocześnie daremność własnych wysiłków nad wskrzeszeniem jej gdzie indziej, cały swój żal i skrywany gniew zawarł w cytowanych wyżej dziełach. Dziś one już nie istnieją, ale miał je w reskach, czytał i robił z nich wypiski Focjusz a "Vita Isidorii" tak streszczał: "W odniesieniu do spraw Bożych był krańcowo bezbożny, a w dziełach jego pełno jest nowych i plotkarskich bajek ... . Wiarę naszą choć lękliwie, to z nieudolnie zamaskowaną złośliwością nierzadko obszczekuje" 7 . o "Paradoksach" zaś tenże Focjusz tak pisał: "Znajdziesz w nich /.../ wiele nędznych zmyśleń $i$ zadziwiających kłamstw, godnych zaprawdę bezbożnego ateisty Doqmaskiosa. Kiedy światło ewangelii napełniło juź cały świat, on sam leżał w nieprzeniknionych ciemnościach bałwochwalstwa" ${ }^{8}$.

4 Vitae philosophorum 472 /ed. Boissonade/.

5 Por. Joannes Malalas, Chronographia XVIII, PG 97, $661 \mathrm{C}$.

6 H.D

7 Bibliotheca 181, PG 103, 528-532 passim.

8 Tamże, 130, PG 103,413. 
Za grantcą juz dawno podjęto próby zgromadzenia świadectw pogańskich o Chrystusie 1 o chrześcijaństwie. Tylko tytułem przykładu wymieniam dwa takie zbiory: Karl Guggenberger, Texte zur altesten K1rchengeschichte aus nichtchristilchen Autoren, Paderborn 1927, oraz Van Den Boer, Scriptorum paganorum I-IV saec. de christianis testimonia, Leiden 1965. Plerwsza pozycja podaje teksty w przekładzie, druga tylko oryginale.

\section{G A L E N \\ W $8 \mathrm{t} \& \mathrm{p}$}

Galen z Pergamonu /+ ok. 200 p. Chr./, nadworny lekarz cesarza Kommodusa, najsławniejszy. po Hipokratesie/t ok. 377 prz. Chr./ autorytet medycynie az do XVI w., a u Arabów do dziś, by 1 autorem licznych pism medycznych, fllozoficznych, gramatycznych 1 retorycznych. Wiele jego dzieł przepadło. Fragmenty niektórych zachowały 810 przekładach arabsk1ch. Ponizszy eragment, zawierajacy wysoka ocene moralności chrześcijan, zachował nam wrzekładzie arabskim uczony érednlowieczny Abul Fida/+1331/, autor wielu dzieł, wóród nich "Historil przedislamskiej", whórej mieści się omawiany fragment. Ostatni badacz Galena, Ryszard Walzer, wynalazł w jego dzierach szé́ć miejsc odnoszących się do Żydów i chrześcijan, których Galen zdaje się nie odrózniać. Nie potępia ich zycia 1 nauki, jak Celsus, nie lekceważ $1 \mathrm{ch}$, Jak Marek Aurel1, nie jest wobec nich wrozi, jak Porfiriusz. Jednym 1 drugim zarzuca nienaukowość. Kosmogonia Mojzesza jest dla niego nie do przyjęcia z powodu mnóstwa cudów. Ogromny podziw ma natomiast dla etycznej postawy chrześcijan, podziwia 1 chwali $1 \mathrm{ch}$ moralna siłe /A/. Pewnym $1 \mathrm{ch}$ niedostatkiem jest niekrytyczny dogmatyzm 1 latwowierność /B, C/.

B 1 b 11 O c r a $\mathbf{f} 1$ a:

P. De Labriolle, La réaction paienne. Etude sur le polemique antichrétienne du Iér au $\nabla^{e}$ siecle, Paris 1934, 94-97. R. Walzer, Galen on Jews and Christians, London 1949. N. Turchi, Gaien, ECat V 18641866. G.Sarton, Galen of Pergamon, Kansas 1954, 85-87. L.Baur, Galenos, LThK IV 491. F.Kudlien, Galenos aus Pergamon, Kleine Pauly II, 674-675. R. Walzer, Galenos, RAC VIII 777-786. T.Sinko, Literatura greoka, III, cz.2, Wrockaw 1954, 151-153. T.Sinko, Zarys historii literatury greckiej, II, Warszawa 1959, 362-364; WEP IV 84. Polskie encyklopedie katolickie hasła Galen nie uwzględniły. 


\section{A. Podziw dla moralności chrześcijan}

Za czasów Galena wzrosła już ogromnie religia chrześcijańska. W książce pt. "Poglądy Platona w dziele 0 państwie" wspomina o nich Galen tymi słowy:

Wielu ludzi nie potrafi ogarnąć myślą toku długich wywodów, dlatego trzeba ich pouczać za pomocą mitów /a rozumie przez nie opoweści o nagrodach 1 karach w życiu przyszłym/, jak to widzimy za naszych czasów u ludzi, którzy nazywają się chrześcijanami, a wiarę swoją opierają na mitach. Jednakże postępują oni niekiedy tak, jak wyznawcy prawdziwej filozofil. Widzimy przecież, jak gardzą śmiercia, a wstydliwościa wiedzeni stronią od zycia płciowego. Sa między nimi kobiety 1 mężczyźni, co przez całe życie wstrzymują się od zbliżeń cielesnych. Są 1 tacy, co w panowaniu nad sobą 1 dyscyplinie wewnętrznej oraz w usilnej pracy nad sobą takie poczynili postępy, iz wcale nie ustępują tym, co weszli na drogę prawdziwej filozofitx.

\section{B-C. Latwowierność chrześcijan}

Aby nikt zaraz na początku, gdyby przyszedł do szkoły Mojzesza 1 Chrystusa, nie słuchał niedorzecznych praw ${ }^{x x}$.

Latwiej mozna czegoś nauczyć zwolenników Mojżesza 1 Chrystusa, niz lekarzy 1 filozofów, przywiązanych do określonych nauk ${ }^{x x x}$.

$x \quad$ Przekład według tekstu: Abulfida, Historia anteislamica, ed. Fleischer, Leipzig 1831, 109; por. W. Den Boer, Scriptorum paganorum I-IV saec. de Christianis testimonia, Leiden 1965, 12 ; Kirch 154 .

xx Przekład według tekstu: De pulsuum differentiis II 4, ed. Kahn, Medicorum Graecorum opera, VIII, Leipzig 1824, 579; por. Den Boer 12 .

xxx Tamże, 657 . 
II. A M M I A N U S M A R C E L L I N U S

$$
\text { W } s \text { t } \mathrm{p}
$$

Był to największy po Tacycie pogański historyk rzymski. Urodzony w Antiochii ok. 330 r., zmarł w Rzymie ok. 400 r. Był oficerem w armii rzymskiej, brał udział w wielu wyprawach wojennych, towarzyszył Julianowi Apostacie w wyprawie na Persów /363/. Po jej ukończeniu osiedlił się w Antiochii, a ok. 380 przeniósł się na stałe do Rzymu i oddał się pisaniu swego historycznego dzieła "Res gestae" w 31 księgach, które miało być kontynuacją Tacyta i objąć czasy od Nerwy $/ 96 /$ do śmierci Walensa /378/. Zachowały się z niego tylko księgi 14-31 za lata 353-78. Opisuje w nich wypadki 25 lat, których był naocznym świadkiem. Jest $z$ pochodzenia Grekiem, lecz z poczucia Rzymianinem. Pisze językiem łacińskim, niestety dość ciężkim, przechodzącym czasem w żargon żołnierski.

Swiatopogląd autora determinuje panujący wówczas neoplatonizm. Na człowieka, Boga i religie patrzy oczyma neoplatonika. Uznaje fatum, niektóre bóstwa, rózne formy kultu pogańskiego, wieszczbiarstwo /potępia jednak szarlatanów/, odrzuca zabobonną astrologię. Przy tym wszystkim idea monoteistyczna nie była mu obca.

Autor żył w czasach pełnego rozkwitu chrześcijaństwa i stykał się z nim często. Jest też w stosunku do niego bardziej obiektywny, niż inni współcześni poganie. Nie widać u niego tej wrogości, jaka rzuca się w oczy u Rutiliusza Namatiana i nie ignoruje go teź ostentacyjnie, jak Makrobiusz. Nie rozumiał jednak sensu sporów ariańskich. Wydawało mu się, że to tylko walka o słowa. Doceniał natomiast znaczenie męczeństwa u chrześcijan /XXII 11,10/, z uznaniem podnosił skromny tryb życia biskupów prowincjonalnych i bronił chrześcijan przed zarzutem, że nie maja miłości ojczyzny /Xx 7,9/. Znał ogólnie hierarchię katolicką: na jej czele stoi "aucto- 
ritate potior aeternae urbis episcopus"/ XV 7,10/, któremu podporzadkowani są biskupi, zmani przez niego antistites. W toku swej narracji porusza wiele spraw kościelnych, a czyni to na ogóz obiektywnie. Sądy ma wywazone. Widaé to np. w odniesieniu do cesarza Jullana Apostaty, którego chociaz był przyjacielem i entuzjasta, to jednak jego posunięć antychrześcijańskich nie tylko nie pochwalał, ale bez ogródek je ganłł. Słowem - opinłe Ammiana wnoszą do naszej znajomości chrześcijaństwa drugiej połowy IV w. wiele pozytecznych uzupełnień 1 znamiennych ocen pochodzących od świadka obserwującego je z boku. Niestety brak polskiego przekładu zagradzał droge do niego studentom historil świeckiej 1 kościelnej. Prezentowany nizej przeze mnie wybór zawiera niemal wszystkie jego wypowiedz1 o chrześcijaństwie. Pominąłem tylko wzmianki krótkie i bez znaczenia.

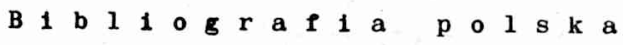

A.Bułakowski, Ammian Marcellin, EKość I 199. Z.Chełmicki, Ammianus Marcellinus, PEK I 175. K. Morawski, De scriptoribus Romanis III et IV post Chr.N. saeculi observationes /De ... Amiano Marcellino .... Kraków 1921, 7-8 /PAU Wydział Filologiczny - Rozprawy, t. LX. Nr $2 \%$ K.Morawsk1, Zarys literatury rzymskiej, Kraków 1922, 310-312. M.H. Serejoki, Ideały Ammiana Marcellina w świetle analizy jego dzieła, "Przegląd Historyczny" 26/1927/285-289. B.Bilińsk1, Najstarsze swiadectwa starożytne oWiśle, "Eos" 42/1947/ 202-206. M.Plezia, Greckie 1 łacínskie źródła do najstarszych dziejów Słowian, Cz.I /do VIII W./, Poznań 1952, 48-51. Przekład i opracowanie 22, 8, 38$40131,2,13-15$. M. Plezia, Neurowle w swietle historiografil starozytnej, "Przegl ąd Zachodni" 5-6/1952/ 253-256. M.Plezia, Hekataios ther die Volker am Nordland des skytischen Schwarzmeergebietes, "Eos" 50/1959-60/27-42. M.Plez1a, Ammianus Marcellinus, Słownik Starozytnośc1 Słowlańskich 1/1961/22. M.Brozek, Historia'literatury łacińskiej otarozytnośc1, Wrocław 1969, 488-489. A.Krawczuk, Ammiana Marcollina relacje 1 éikcje. Sprawozdania PAN, Kraków 1972, t. 16, 375-376. H.Cichocka, Czwartowieczny opis wybrzeży Morza Czarnego. Ammiański opis wybrzezy Morza Czarnego/przekład/, "Nautologia" 7/1972/ 69-80. L.Małunowiczówna, Ammian Marcellin, EK 1 457. H.C1chocka, Ammianus Marcellinus a literatura grecka 1 rzymska, "Meander" 29/1974/289-306. S.Stabryła, Nowele rzymskie. Wybrał, przelozy 1 opracował ... Warszawa 1975, 234-237. - Przekład Res gestae XVIII 10, 1-3; XIX 9, 3-8 o zonie Kraugazjusza. H.Cichocka, Mowy 1 listy " "Res gestae" Ammiana Marcellina, "Meander" 30/1975/157165. Tenże, Zależność Ammiana Marcellina od Solinusa w ekskursie - Egipcie /XXII 15-16/, "Meander" 30/1975/336-352. Tenże, Amianus Marcellinus, Ekskurs o Eg1pcie / XXII 15-16/. Przełożia... "Meander" 30/1975/422-430. Tenze, Die Konzeption des Exkurses" $1 \mathrm{~m}$ Geschlchtswerk des Ammianus Marceilinus, "Eos" 63/1975/329-340. A.Krawczuk, Ostatnia olimpiada, Wrocław 1976, 107-111/rozdz.pt. 
"Historyk 1 jego dzieło"/. H.Cichocka, Ammianus Marcellinus o Aleksandrii /ekskurs o Egipcie XII 15-16/, w: Starożytna Aleksandria w badaniach polskich. Materiały Sesji Naukowej zorganizowanej przez Instytut Archeologii Uniwersytetu Jagiellońskiego, Kraków 8-9 kwietnia 1975, Warszawa 1977, 161-168.

$$
P \quad r \quad z \quad k \quad z \quad a d^{x}
$$

\section{A. Przekonania religijne Ammiana}

XIV 11, 25-26. Takich i innych niezliczonych tego rodzaju dzieł dokonuje niekiedy Adrastia ${ }^{1}$, mścicielka złych czynów 1 nagrodzicielka dobrych - oby tylko zawsze! My /= Grecy/ nadajemy jej takze drugie imię Nemesis, to jest pewne wzniosłe prawo bóstwa/numen/ działającego według opinii ludzkiej ponad sferą księźyca, albo jak Inni definiują, substancjalny duch opiekuńczy ${ }^{2}$, kierujący wszechmocnie losami poszczególnych ludzi. Starzy teologowie wyobraźali ją sobie jako córkę Sprawiedlíwości i podawali, że spogląda na sprawy ludzkie z jakiejś odwiecznej, ukrytej sledziby. Jako królowa spraw spornych jest rozjemcą $i$ kierowniczką wszelkich spraw $i$ wstrząsa urną z losami. Ona to powoduje zmienność bieżących wydarzeń 1 kieruje niekiedy budzące się u nas życzenie w inną stronę, niż by śmy chcie11, ponadto wielu czynnościom nadaje inny obrót i koniec $/ \ldots /$.

Dlatego to skłonna do baśni starożytność /fabulosa vetustas/ przyprawiła jej skrzydła, aby wszyscy nabrali przekonania, że zjawia się wszędzie z chyżością ptaka, i dała jej ster do rąk, a pod

x Przekładu dokonano według tekstu krytycznego zawartego w: Ammianus Marcellinus, Romische Geschichte, I-IV Teil, Lateinisch und deutsch mit einem Kommentar von W.Seyfarth, Beriin 1968-1971, Akademie-Verlag.

1 Adrastia = Nemesis, w mitologii antycznej pojmowana była jako mścicielka zbrodni i poskromicielka pyszałków. Por. Horacego Carmina I 34, 13-16 o Jowiszu:

"Dumne wielkości Bóg poniza czasem,

A w górę dźwiga proch upokorzony:

Jednym Fortuna $z$ niezmiernym hałasem

Zrywa, a drugim rozdaje korony.

Tłum. Lucjan Siemieński

2 Substantialis tutela. 
stopami ustawiła koło, aby wszyscy wiedzieli, że rządzi wszechświatem przebiegając przez wszystkie elementy.

\section{B. "Conventiculum ritus christiani"}

XV 5,31. Ustalono plan całej akcji ${ }^{3}$ przy pomocy szeregowych żołnierzy, przez swą niepozorność szczególnie przydatnych do takich działań. Zapalona nadzieją na nagrodę wpadła grupa zbrojnych już o pierwszym brzasku dnia, $i$ jak to bywa w sytuacjach trudnych do przewidzenia, rozzuchwaliła się, wymordowała straż, wtargnęła do pałacu, wyciągnęła Sylwana z kaplicy ${ }^{4}$, dokąd zbłegł na pół żywy ze strachu, a kiedy próbował się schronić w miejscu zgromadzeń obrządku chrześcijańskiego ${ }^{5}$, zginął pod gęstymi ciosami mieczy.

\section{0 papieżu Liberiuszu i biskupie Atanazym}

XV 7, 6-10. Za kadencji Leoncjusza ${ }^{6}$ wydał Konstancjusz ${ }^{7}$ zarządzenie, żeby Liberiusza ${ }^{8}$, zwierzchnika wiary chrześcijańskiej, wysłać na dwór cesarski, ponieważ rozkazom cesarskim i większości swych kolegów w urzędzie stawiał opór w sprawie, którą pokrótce przedstawię.

Atanazy, ówczesny biskup Aleksandrii, wynosił się - według uporczywych pogłosek - wysoko ponad stanowisko i usiłował dowiedzieć się niedozwolonych rzeczy. Zwołane tam licznie obesłane zgromadzenie - nazywaja je synodem - złożyło go z piastowanego urzędu. Zarzucano mu, że dawał wiarę wróżbom i losom, że dociekliwie badał

3 Piąty rozdział księgi XV poświęcony jest Sylwanowi, Frankowi $z$ pochodzenia, katolikowi z wyznania, który jako magister peditum /dowódca piechoty/ został wysłany za Konstancjusza do Galii i tu wolonii obwołano go 11 VIII $355 \mathrm{r}$. cesarzem. Szybko jednak obmyślano plan usunięcia go $i$ w trzy tygodnie póniej został zamordowany.

4 Aedicula.

5 Conventiculum ritus christiani. Tak określa Ammian świątynię chrześcijańską, tj. kościół.

6 Flavius Leoncjusz, quaestor sacri palatii za Gallusa $/ 354 /$, praefectus urbi /356/. Pochodził ze Wschodu i był senatorem w Konstantynopolu.

7 Konstancjusz, cesarz 350-361, wojujący arianin.

8 Liberiusz, papież 352-366. 
co wróżyły ptaki augurów i że kilka razy przepowiadał przyszłość. Ponadto obwiniano go o inne jeszcze występki sprzeczne z religia, w której zajmował kierownicze stanowisko.

Liberiusz został wówczas przez cesarza wezwany, by przyłączył się do zdania innych, co rozkaz cesarza przyjęli $i$ podpisał złożenie Atanazego ze stolicy biskupiej. Oparł się jednak stanowczo i bez przerwy twierdził, że to skończona niegodziwość potępiać człowieka, którego się nie widziało, ani nie przesłuchało. Cesarz bowiem, wrogo do niego zawsze nastawiony, choć wiedział dobrze, że sprawa jest już załatwiona, to jednak gorąco pragnął, żeby decyzję przez siebie powziętą zatwierdził zwierzchni autorytet biskupa wiecznego miasta ${ }^{9}$. Tego jednak nie uzyskał. Wywieziono więc Liberiusza na wygnanie. $Z$ obawy przed ludem, który darzył go ogromną miłością, dało się to zrobić tylko z największą trudnością i pod osłoną nocnych ciemności.

\section{Dziewice chrześcijańskie na Wschodzie}

XVIII 10, 2-4. Wiedziony cheiwością rabunku cudzych rzeczy zdobył /Sapor II"10/ nagłym atakiem dwie twierdze /Reman i Busan/ ${ }^{11}$. Powstała nieopisana panika, bo obrońcy przerażeni różnorodnością broni wroga, poddali się razem ze wszystkimi, którzy szukali tam schronienia /.../. Znaleziono tam ponadto inne dziewice poświęcone służbie Bożej według obrządku chrześcijańskiego. Sapor polecił je strzec, aby nie doznały krzywdy i mogły bez przeszkód z czyjejkolwiek strony i zgodnie ze zwyczajem służyć religii. Oczywista, udawał wówczas łagodność, aby wszyscy, u których przedtem budził trwoge

9 Auctoritate potiore aeternae urbis episcopi - znamienne słowa autora pogańskiego napisane ok. $390 \mathrm{r}$. Pogląd Ammiana potwierdza sam Atanazy: "Ci bezbożni ludzie /arianie/ sądzili, że jeżeli oszukają Liberiusza, od razu odniosą zwycięstwo na wszystkimi. Dlatego obrzucali go kalumniami przed cesarzem. Cesarz zaś ze swej strony spodz1owając się, że przy pomocy Liberiusza zjedna sobie wszystkich, posyła w imieniu Euzebiusza eunucha z listem i darami" /...//PG 25,734\%.

10 Sapor II, król Persów /310-379/, główny przeciwnik cesarstwa rzymskiego na Wschodzie w IV w.

11 Chodzi o miasto Charcha w rejonie Amidy. 
przez swoją dzikość i okrucieństwo, wyzbyli się strachu i dobrowolnie przystali do niego. Te świeże przykłady miały ich przekonać, że dzięki poczuciu ludzkości i łagodnym już obyczajom sprowadzix do właściwej miary ogrom swojego szczęścia.

\section{E. Dyplomatyczna misja biskupa u króla Sapora}

Kiedy król perski Sapor oblegał miasto Bezabdę w Mezopotamii, pewien biskup12 udał się w czasie chwilowego zawieszenia broni do obozu króla doradzajazc mu zaprzestanie oblężenia, bo wojna pochłonęła już wiele ofiar ludzkich.

XX 7, 8-9. Jednakże kiedy mu to $i$ wiele jeszcze innych podobnych rzeczy przedkładał, okazało się to daremne, bo na przeszkodzie stanęła szalona wściekłość króla, który z uporem przysięgał, że nie zawróci, dopóki nie zburzy twierdzy. W związku z tym padło na biskupa nieuzasadnione, jak sądzę, podejrzenie, jakkolwiek wielu taką pogłoskę rozsiewało jako prawdę. W rozmowie z Saporem w cztery oczy miał mu jakoby wskazać, w jakich miejscach murów powinien przeprowadzić atak, bo tam były wewnątrz zmurszałe i słabe. Ta pogłoska wydała się prawdopodobna dlatego, że później machiny wojenne wroga rozpoczęły świadomie atak na miejsca niezabezpieczone i grożące zawaleniem, jak gdyby chytrze kierował tym ktoś z wewnątrz.

\section{F. Obłuda Juliana}

XXI 2, 2-5. Julian, będąc jeszcze cezarem ${ }^{13}$, odpoczywał w Vienne /.../. Aby wszystkich bez czyjejkolwiek przeszkody przyciągnąć do siebie, stwarzał pozory, że należy do religii chrześcijańskiej ${ }^{14}$, od której już przedtem odpadł potajemnie, aby móc oddawać się wróżbiarstwu i wieszczbiarstwu i innym obrzędom praktykowanym zawsze przèz czcicieli dawnych bogów. 0 tej tajemnicy niewielu tylko wiedziało. Ażeby zaś to na razie ukryé, udał się w święto, jakie chrześcijanie obchodzą w styczniu i nazywają Epifanią ${ }^{15}$, do ich

12 Imienia Ammian nie podaje.

13 Opisane wydarzenie miało miejsce w $360 \mathrm{r}$., kiedy Julian nie by $\mathbf{3}$ jeszcze augustem, lecz tylko cezarem, namiestnikiem Galii.

14 Znamienne wyrażenie świadczące, że ludność miast ówczesnej Galii była już katolicka.

15 Ranga święta Epifanii /Objawienia Pańskiego/, obchodzonego 
kościoła $i$ opuścił go dopiero wtedy, gdy uroczyście pomodlił się do bóstwa 16 .

\section{G. Polityka religijna Konstancjusza}

XXI 16, 18. Cesarz Konstancjusz wprowadził do zwartej $i$ prostej wiary chrześcijańskiej zamieszanie przez babskie i zabobonne zniekształcenia, przy czym więcej dawał powodów do jałowych dyskusji, niż do rzetelnego załatwienia. Spowodował przez to wiele sporów, które rosnąc dalej przechodziły w kłótnie o słowa/concertatio verborum/17 i powodowały całkowitą dezorganizację komunikacji, bo tłumy biskupów jeździły tam i z powrotem państwowymi zaprzęgami na tzw. synody, chcąc pozyskać innych dla swoich opinii.

\section{H. Taktyka antychrześcijańska cesarza Juliana}

XXII 5, 1-4. Jakkolwiek od najwcześniejszej młodości skłaniał się Julian coraz wyraźniej ku czci bóstw, a w miarę, jak dorastał, skłonności te coraz więcej się rozpalały, to jednakże żywiąc wiele obaw, podejmował pewne kroki w tym kierunku w największej możliwie tajemnicy. Kiedy te obawy opadły, spostrzegł, iż nadszedł czas swobodnego działania według jego woli, odsłonił tajemnice swego serca i w otwartych a stanowczych dekretach nakazał otworzyć świątynie, składać na ołtarzach zwierzęta ofiarne/hostias/i wskrzesić kult

6 stycznia, była wówczas tak wielka, że nawet ludzie pokroju Juliana czuli się zmuszeni, przynajmniej dla oka, brać w nim udział. 0 podobnym wypadku $z$ arianizującym cesarzem Walensem opowiada Grzegorz z Nazjanzu w mowie na cześć Bazylego/Oratio 43, 53, tłum. J.M.Szymusiak, zob. Św.Grzegorz z Nazjanzu, Mowy wybrane, Warszawa 1967,505 .

16 Uczestniczenie Juliana w uroczystości Epifanii 6 I 361 było ostatnim jego aktem udziału w kulcie katolickim. Por. B. De GaifPier, "Sub Juliano Apostata" dans le Martyrologe Romain, "Analecta Bollandiana" 74/1956/ 6 .

17 Poganin Ammian stoi tu na stanowisku ariańskiego cesarza Konstancjusza $i$ nie dostrzega, ze w sporach o homoousios i homoiousios chodziło o podstawę chrześcijaństwa, tj. o bóstwo Chrystusa. Ta jedna litera "i"/iota/ decydowała, czy stoi się na stanowisku katolickim, czy ariańskim. 
bogów ${ }^{18}$. Aby zaś te rozporządzenia przyniosły trwałe wyniki, zwołał do pałacu poróżnionych ze sobą biskupów chrześcijańskich 1 skłócony lud, napominając ich łagodnie, aby położyli kres niezgodzie, i aby kaźdy bez przeszkód 1 obaw służył swojej religil. Kroki te podejmował z uporem w tym celu, aby dając im większą swobodę, spotęgować wśród nich spory 1 nie mieć na przyszłość obaw ze strony jednomyślnego ludu. Wiedział bowiem z doświadczenia, że nie ma tak wrogich dla ludności bestii, jakimi są większości zionący nienawiścia ku sobie chrześcijanie.

\section{Opinia o edykcie Juliana z $362 \mathrm{r}$.}

XXII 10, 6-7. Dzięki tym i innym poczynaniom, o których sam często przypominał, mogło się wydawać, że stara bogini Sprawiedliwości obrażona występkami ludzkimi, 1 dlatego przez Arata ${ }^{19}$ przeniesiona do nieba, teraz za jego panowania powróciła na ziemie. Jednakże pewne kroki podejmował według własnego widzimisię i niezgodnie z prawem. Na skutek tego miejeden raz pobłądzil 1 zaciemnił chwałę swych licznych czynów. Po wielu innych posunięciach poprawił równiez pewne prawa usuwając z nich dwuznaczności, tak iż jasno wskazywały, co nakazuja, a czego zabraniają. Wszelako nieludzkie /inclemens/ $i$ zasługujące na pogrzebanie w wiecznej niepamięci było to, że nauczycielom, retorom 1 gramatykom wyznania chrześcijańskiego zabronił nauczania /arcebat docere/20.

18 W związku z tym posunięciem Juliana, Józep Lecler pisze: "Na przykładzie Juliana Apostaty/361-363/ moźna sie przekonać, jak bardzo niepewna w tym czasie była każa deklaracja wolności kultów /.../. W tym posunięciu było sporo perfidii" /Historia tolerancji w wieku reformacji, t.1, Warszawa 1964, 75-76/.

19 Aratos z Solo1 w Cylicji /ok. 310-245 prz. Chr./, grecki epik dydaktyczny, autor wielu dzieł, z których najsłynniejsze sa "Fainomena"'/Zjawiska na niebie/. Poemat zaczął od hymnu do Zeusa, z którego wiersz 5 przytacza św. Paweł w swej mowie na Areopagu /Dz 17,28: "Jesteśmy bowiem z jego rodu"/; por. T.Sinko, Literatura grecka, dz.cyt. II 1, 284-297; Tenze, Zarys historii literatury greckiej, dz.cyt., II 187-194.

20 Źaden dekret prześladowczy Juliana nie wywołał u chrześcijan takiego poruszenia a nawet wzburzenia, jak ten odsuwajacy ich od szkół. Wyraz oburzenia dali m.in.: Sokrates, HE III 12,16, PG 67, 412,417; Sozomen, HE V 18, PG 67, 1269; Grzegorz z Nazjanzu,
Contra Julianum I 5, 101-112, PG 35, 536, 636-649; Augustyn, Confessiones VIII 5,10 , PL 32,753 ; Tenże, De civitate Dei XVIII 52,2 , PL 41,615; Codex Theodosianus 13,3,5/= Cod.Just. 10,53, 


\section{J. Artemiusz $/+362 /$}

XXII 11,2. Wówczas to rómniez Artemiusz ${ }^{21}$, były dowódca Egipeie, został skazany na śmieré, ponieważ Aleksandryjczycy obc1azyli go mnóstwem cięzkich zbrodni.

\section{K. 0 biskupie arianskim Georgiosie/Jerzym/}

XXII 11, 4-5, 10. Był on 22 , Jak wieść niesie, synem rolusznika. Urodził się Epifanil, mieście Cylicj1 1 na szkodę bardzo wielu

7\%. Złowrózbne znaczenie tego dekretu Juliana omówił u nas Kazimierz Morawski, Julian Apostata, w: Rym. Portrety 1 szkice, Krakón 19242, 244-245. Powtórzył to ks. Stepan Abt, Wypisy do dzieJów Kościoła powszechnego, Poznań 1930, 148-150. Por. tez Charles Norris Cochrane, Chrześc1jaństwo 1 kultura antyczna, Warszawa 1960, 283-284.

21 Stanowisko religijne Artemiusza nie jest jednoznaczne. Popieral arianskiego bpa Georgiosa/Jerzego/, Intruza na stolicy aleksandryjskiej po wygnaniu Atanazego, którego ścigając dotarł az do klasztorów $w$ Tabennisi w błędnym mniemaniu, ze tam sie ukryma. Nieprzychylnie by 1 nastawiony do wyznawców nicejskich, ale nie oszczędzał tez pogan, których świątynie łupił 1 burzył. Oskarzony zostal o to przez nich przed cesarzem Julianem $/ 362 /$, który, według świadectwa Teodoreta, "nie tylko skonfiskował mu majatek, lecz takze kazał go w koŕcu ściać. Takich to 1 tym podobnych czynów dokonywał ten, którego bezbożni nazywają najłagodniejszym 1 stawlają go za wzór panowania nad sobą"/Teodoret, HE III 18\%. Ciało Artemiusza przewieziono do Konstantynopola 1 z oznakami czc1 złozono w kościele sw. Jana Chrzciciela. Umieszczenie go Martyrologium Rzymsk $1 \mathrm{~m} / 20 \mathrm{X}$; Com.Mart.Rom. 465/ starzy bollandyści tłumacza tym, ze choc trzymał $z$ arianami 1 nie przeszkadzał okrucienstwom Georglosa, nie był jednak zupełnie bezboznym, bo religijnie potraktował tabennisiotów, prosił $1 \mathrm{ch} 0$ modlitwy i sam sie modlil; por. Acta SS.Octobris VIII, 847-885; Synaxarium Ecclesiae Constantinopolitanae 151-153; Ph1lostorgius, Kirchengeschicht $\theta$, ed. J.Bidez, XLIV-LXVIII, 166-175; P.Battiffol, "Rømische Quartalschr1ft" 1889, 252-289; B. De Gaiffier, "Sub Juliano Apostata" dans le Martyrologe Roma1n, "Analecta Bollandiana" 74/1956/15-16; M.V.Brand1, Bibliotheca Sanctorum, II, Roma 1962, $488-489$.

22 Georgios/Jerzy/z Eplfanil/Cyllcja w Azj1 Mn./, nazywany zazwyczaj Kapadocczykiem, był po wygnaniu Atanazego arlańskim biskupem Aleksandri1 i stanowczym wrogiem pogan. Juz w r. $358 \mathrm{mu}-$ sial przed nimi uciekać, ale $\$ \$ 61 \mathrm{r}$. powrócił. Na wiadomóćc o wstapieniu na tron Juliana, mieszkancy zbuntowali się przeciw niemu 1 "na miejscu go zabili, a wsadziwszy zwłoki na grzbiet wielbłąda przez cały dzleń naigrywal1 się z niego, aź późnym czorem wrzucili szczątki do ognia"/Sozomen, HE V 7/. Ten postępek pogan zganił Julian specjalnym liścle do Aleksandryjczykón, wyrazając zdumienie, ze "pospólstwo ma odwage rozerwá człow1eka 
ludzi zrobił karierę, a na przekór własnej korzyści i pożytkowi ogółu został wyświęcony na biskupa Aleksandrii, miasta, które na skutek swej porywczości nawet gdy nie ma żadnego powodu, bywa wstrząsane częstymi i burzliwymi rewoltami, co zresztą potwierdzają nawet wyrocznie. Dla tych popędliwych ludzi już sam Georgios/Jerzy/stał się kamieniem obrazy, zwłaszcza że od razu zanosił do szeroko otwartych uszu Konstancjusza skargi na wielu obywateli, jakoby stawiali opór jego rozkazom. Postępował tak, bo puścił w niepamięć zasady swojej religii, która nakazywała nic innego, jak tylko sprawiedliwość i łagodność. On zaś posunął się do roli obrzydliwego denuncjatora /.../

W dalszym ciągu opisuje Ammian bezprawia Georgiosa i zlinczowanie go, gdy obraził ich uczucia religijne. Wspomina dalej o zamordowaniu dwóch nadgorliwych chrześcijan i kończy taką uwagą'o męczennikach chrześcijańskich/:

Ale na tym nie poprzestał tłum w swym okrucieństwie. Rozszarpane zwłoki zamordowanych załadował na wielbłądy i zawiózł nad brzeg morza, tam rozniecił ogień i spalił je na popiół i rozsypał w morzu w obawie - jak wynikało z okrzyków - żeby nie pozbierano resztek i nie zbudowano im świątyń jak innym, którzy przymuszeni do zaparcia się religii, znieśli straszliwe katusze i pozostając wierni swej wierze wytrwali aż do chwalebnej śmierci i teraz noszą nazwę męczenników. Można by było uratować tych nieszczęsnych ludzi przy pomocy chrześcijan w momencie, kiedy prowadzono ich na stracenie, gdyby wszyscy bez różnicy nie byli rozpaleni nienawiścią do Georgiosa".

\section{Podejrzliwość cesarza Juliana}

XXII 13, 1-3. W tym samym czasie, dnia 22 października /362/, stanęła nagle w płomieniach wielka świątynia Apollina z Dafne 23 , zbu-

na strzępy tak, jak psy zajadłe"/Sokrates, HE III 3/. Dosadną charakterystyke Georgiosa dał Grzegorz z Nazjanzu wowie ku czci Atanazego / Oratio 21, 16/.

23 Przedmieście Antiochii ze słynną świątynią Apollina i wyrocznią, która za czasów Juliana już zamilkła. Zob. Rufin, HE I 35, tłum. A.Bober /Antologia patrystyczna, Kraków 1965/, 201-202. W'Dafne był również wielki park miejski z wszelkimi urządzeniami sportowymi $i$ wypoczynkowymi, które stwarzały różne zagrożenia dla moralności. Sw. Jan Chryzostom wielokroć pomstował w swych kazaniach na ten gaj Dafne. Zob. Chr.Baur, Johannes Chrysostomus und seine Zeit, I Munchen 1929 wg indeksu i W.Ceran, Rzemieślnicy i kupcy 
dowana przez znanego, gniewnego 1 okrutnego króla Antiocha Epifane$\mathrm{sa}^{24}$, a wiej posąg dorównujący wielkością Zeusowi Olimpijskiemu ${ }^{25}$. Kiedy na skutek tego strasznego i niespodziewanego przypadku świątynia została całkowicie zniszczona, gniew cesarza posunał się tak daleko, że zarządził znacznie surowsze niż zwykle dochodzenia oraz zamknięcie wielkiego kościoła w Antiochii ${ }^{26}$. Podejrzewał bowiem, że dokonali tego chrześcijanie z zazdrości, bo widzieli, że ta świątynia jest otoczona wspaniałym peristylem. Jednakże uporczywa pogłoska, choć tylko po cichu przekazywana $z$ ust do ust, utrzymywała, iż świątynia spłonęła z tego powodu, że filozof Asklepiades ${ }^{27}$, o którym wspomnieliśmy omawiając historię Magnencjusza, który przybył z daleka na przedmieście Dafne, aby zobaczyć Juliana, postawił niewielki srebrny wizerunek niebieskiej bogini, który zawsze nosił przy sobie dokądkolwiek się udawał, u stóp wyniosłego posągu, zapalił świece i swoim zwyczajem odszedł. Tymczasem o samej północy, kiedy w pobliżu nie było nikogo, kto by mógł pośpieszyć na ratunek, dobywające się iskry dosięgły bardzo starej, wysuszonej i latwopalnej materii 1 spowodowały ogólny pożar. Dokąd tylko dosięgnął ogień, nawet do przedmiotów stojących wysoko $i$ wznacznej odległości, wszystko strawił.

M. Daremne wysiłki Juliana nad odbudowa światyni jerozol1mskiej/363/

Ten sam wypadek opisują: Efrem, Pieśni przeciw Julianowi Apostacie /Die Gedichte des heiligen Ephrlm gegen Julian den Apostaten, "Zeitschrift fur Katholische Theologie" 2/1878/335-356/; Grzegorz z Nazjanzu, Oratio 5,4, PG 35, 667-668; Ambroży, Epistola 42, P1 16,1172; Jan Chryzostom,

w Antiochii i ich ranga społeczna, Warszawa 1969, 22.

24 Postać znana z Ksiąg Machabejskich /II w. prz. Chr./. Jednakże świątynię zbudował Seleukos Nikanor /III w. prz. Chr./.

25 Arcydzieło najznakomitszego mistrza rzeźby greckiej z V w. prz. Chr., Fidiasza. Posąg Zeusa w Olimpii ze złota i kości słoniowej /chryzoelefantyna/ miał $9 \mathrm{~m}$. wysokości.

260 tym kościele zob. J.Chr.Baur, Johannes Chryzostomus und seine Zeit, dz.cyt. wg indeksu.

270 jednej z zaginionych ksiag mniejszego dzieła Asklepiadesa, bliżej nieznanego filozofa cynickiego, wspomina Julian /Oratio 7,224/i Symmach /Epistola 5,31/. 
Adversus Judaeos 5, PG 48,900; Contra Julianum et gentiles, quod Christus sit Deus, $P G 50,5 \leq 0$; In Mat thaeum hom. 4,1, PG 57,41, Krystyniacki I 35; Rufin, HE I 38; Orozjusz, Adversus paganos VII 30; Filostorgiusz, HE VII 9,14; Sokrates, HE III 20; Sozomenos, HE V 22; Teodoret, HE III 20 i wreSzcie sam Julian, Epistola $25 ;$ zob. R.Konecki, Cesarza Juliana Apostaty próba odbudowania świątyni żydowskiej w Jerozolimie, "Przegląd Teologiczny" 2/1921/40-59, 281-313, 3/1922/

XXIII 1, 2-3. /Cesarz Julian/ choć bieżącymi sprawami troskliwie kierował $i$ wielkim zapałem nalegał na wszechstronne przygotowanie wyprawy/przeciw Persom/, to przecież swoją troskę o cesarstwo rozdzielał na różne dziedziny, a chcąc pamięć swojego panowania uwiecznić wielkimi dziełami, postanowił przy użyciu największych nawet kosztów odbudować wspaniałą niegdyś świątynię w Jerozolimie, którą po wielu morderczych walkach osaczył Wespazjan, a później Tytus z największym trudem zdobył. Wykonanie tego przedsięwzięcia zlecił Alpiuszowi z Antiochii, który był przedtem proprefektem w Brytanii. Kiedy więc Alpiusz zabrał się rączo do dzieła, a pomoca mu służył namiestnik prowincji, dobyły się z fundamentów straszliwe płomienie ognia i buchając wysoko raz po raz, spaliły kilka razy robotników, a miejsce uczyniły niedostępnym. W ten sposób na skutek nieprzezwycięźonych trudności ze strony żywiołu, poniechano przedsięwzięcia.

\section{N. Charakterystyka cesarza Juliana}

XXV 4, 16-20. Wyliczywszy zalety, jakie mogliśmy poznać, przejdźmy teraz do wyłuszczenia jego wad, jakkolwiek juź o nich to $i$ owo powiedziałem. Był nieco lekkomyślny, jednakże starał się nad tym panować w ten sposób, że pozwalał, aby go poprawiano, gdy zbaczał z właściwej drogi. Był zbyt gadatliwy $i$ nadzwyczaj rzadko potrafił zamilknąć. Zbytnio był oddany badaniu wróżb $i$ w tym można go było porównać z cesarzem Hadrianem. Stał się raczej czcicielem przesądów niż świętych obrzędów. Bez oglazdania się na oszczędność zabijał na ofiarę niezliczoną llość bydląt, tak iż wyglądało na to, ze gdy powróci z wojny z Partami ${ }^{28}$, wołów już zabraknie. W tym znów

28 Tu 1 gdzie indziej mówi Ammian o Partach, choć ich królestwo upadło w 227 r. a władzę nad nierzymską Azją przejęli Persowie dynastii Sasanidów. 
był podobny do Marka Aurelego, o którym ułożono następujący wiersz:

Białe woły pozdrawiaja cesarza Marka.
Jeźeli znów zwycięzysz - wsystkie zginiemy! 29

Cieszył go poklask tłumu, nieumiarkowanie był chciwy na pochwały nawet za drobnostki. W namiętnej pogoni za popularnością posuwał się nawet do tego, że był skłonny do rozmów z niegodnymi.

Jednakże mimo tego wszystkiego można było sądzić, iż - jak sam to powiedział - stara owa bogini Sprawiedliwości, którą Aratos $^{30}$ przeniósł do nieba, bo obraziła się z powodu ludzkich występków, za jego panowania ponownie wróciła na ziemię, z tym atoli zastrzeżeniem, że pewne kroki podejmował według własnych zachcianek i okazywał się niepodobnym do samego siebie.

Wydał téz znośne prawa, bezwzględnie nakazujące lub zabraniające pewnych rzeczy, jednakże z kilku wyjątkami. Wśród tych ostatnich to było najbardziej nieludzkie, że zakazał nauczania chrześcijańskim nauczycielom, retorom $i$ gramatykom, jeżeli nie przejdą do kultu bożyszcz/numinum/ ${ }^{31}$.

\section{Cesarz Jowian a chrześcijaństwo}

XXV 5,4. /Po śmierci Juliana/ został wybrany cesarzem Jowian ${ }^{32}$, dowódca gwardii, którego zalecały w pewnej mierze zasługi ojca.

XXV 10,15. Chciał naśladować Konstancjusza załatwiając pewne ważne sprawy po południu. Miał zwyczaj dowcipkować publicznie z swym najbliższym otoczeniem. Był gorliwym wyznawcą religii chrześcijańskiej 1 niejednokrotnie dawał tego dowody 33 .

\section{P. Opinia o papieżu Damazym i o wiejskich biskupach}

XXVII, 3, 11-15. Następcą Lampadiusza ${ }^{34}$ został Wiwencjusz ${ }^{35}$ piastujący uprzednio urząd kwestora pałacu cesarskiego, Pannończyk

29 Ten dwuwiersz cytuje Ammian po grecku.

30 Por. notę 19.

31 Por. notę 20 .

32 Jowian, cesarz 363-364.

33 M.in. odwołał Atanazego z wygnania, przywrócił chrześcijanom uprawnienia odebrane im przez Juliana - zob. Sozomen, HE VI 3.

34 Lampadiusz, prefekt Rzymu w $365 \mathrm{r}$.

35 Wiwencjusz, prefekt Rzymu w $366 \mathrm{r}$. 
z charakterem $i$ rozwaga. Władzę sprawował ze spokojem $i$ umiarem. Wszelkich rzeczy było w bród. Jednakże przeraziły go krwawe zamieszki niezgodliwego ludu. Przyczyna była następująca.

Damazy $i$ Ursyn ${ }^{36}$ pragnęli ponad ludzką miarę zawładnąć stolicą biskupią, a ponieważ głosy były podzielone, rozpoczęli przy pomocy swoich zwolenników zażartą walkę, w wyniku której byli zabici i rannii. Wiwencjusz nie mogąc temu położyć kresu, ani zaprowadzić ładu, wycofał się na skutek tych gwałtów na przedmieścia. W walce zwyciężył Damazy dzięki silnemu poparciu stronnictwa, które mu sprzyjało. Stwierdzono, ze w bazylice Sycyniusza ${ }^{37}$, w kórej chrześcijanie odbywają swe zgromadzenia, znaleziono jednego dnia 137 zabitych, a zdziczały przez tak długi czas lud moźna było później tylko z największym trudem uspokoić.

Patrząc na wielkomiejski styl życia rozumiem, że żądni tego powinni cała siłą swych łokci przepychać się, żeby posiąść to, czego pożądają, bo dopiąwszy swego, zabezpieczają się na przyszłość, albowlem bogacą się darowiznami matron. Wyruszają na miasto siedząc w powozach, dostojnie odziani ${ }^{38}$. Uczty urządzają tak wystawne, ze ich przyjęcia przewyższają królewskie stoły. A przecież mogliby oni być naprawdę szczęśliwymi, gdyby nie oglądali się na wielkich tego miasta, których postępowaniem swe błędy usprawiedliwiają, lecz żyli na wzór pewnych biskupów prowincjonalnych, których niezwykła skromność

36 Po śmierci papieża Liberiusza / 366/ biskupem Rzymu został Damazy. Jednakze pewna część ludności zarzuciła mu, ze przez pewien czas popierał antypapieża Feliksa i wybrała na biskupa Rzymu Ursyna /Ursycyna/. Doszło do krwawych walk, które opisuje tu. Ammian, a $z$ pewnym retuszem równiez Rufin /HE II 10/. Ostatecznie cesarz Walentynian I skazał Ursyna na wygnanie. Niepokoje trwały jednak jeszcze długie lata. W $380 \mathrm{r}$. synod rzymski zwrócił się o pomoc do cesarza Gracjana, który uznał jeszcze raz niewinność Damazego, a jego przeciwników skazał na wygnanie.

37 Basilica Sicinini, zwana té bazyliką Liberiusza. Jest to Santa Maria Maggiore na Eskwilinie. Jej budowe przypisuje sie Liberiuszowi. 0,gminie chrześcijańskiej w ówczesnym Rzymie por. K.Gamber, "Revue Bénédictine" 77/1967/148-155; A.Lippold, Ursinus und Damasus, "Historia" 14/1965/105-107; Tenze, Ursinus, RE Suppl.X 1141-1143.

38 Tego rodzaju zewnętrzna pompa weszła widocznie w zwyczaj u niektórych biskupów, skoro Grzegorz z Nazjanzu w swej mowie poźegnalnej po rezygnacji z biskupstwa w Konstantynopolu/koniec czerwca 381 r./ mógł powiedzieć: "Nie wiedziałem, ze miałem posługiwać się wspaniałymi końmi, zasiadać w błyszczących powozach, 
i oszczędność w jedzeniu i piciu oraz prostota ubioru $i$ oczy spuszczone ku ziemi zalecają w obliczu wiekuistego bóstwa i jego prawdziwych czcicieli jako nieskazitelnych i czcigodnych.

\section{R. O męczennikach chrześcijańskich}

XXVII 7,6. Kiedy w procesie pewnego Maksencjusza ${ }^{39}$ z Panonil sędzia zarządził zgodnie z prawem przyspieszenie wykonania wyroku na urzędnikach trzech miast, ówczesny kwestor Eupraksjusz 40 tak odezwał się do cesarza Walentyniana I/: "Postępuj nieco łagodniej, najdostojniejszy cesarzu, albowiem tych, których ty nakazujesz stracić jakoby winnych, religia chrześcijańska czci jako męczenników, to jest miłych Bogu/divinitati acceptos/.

\section{S. Praetextatus przywraca pokój po rozruchach}

XXVII 9, 8-9. Kiedy rozgrywały się te wypadki, stanowisko prefekta Miasta / = Rzymu/ zaszczytnie piastował Praetextatus ${ }^{41}$. Dzięki swej bogatej a nieposzlakowanej działalności 1 swojej uczciwości, czym zasłynął od najwcześniejszej młodości, osiągnął to, co rzadko się zdarza, że mimo, iż budził lęk, to przecież nie stracił sympatil obywateli, która w stosunku do budzących lęk sędziów jest zazwyczaj niezbyt ugruntowana. Jego autorytet oraz słuszne 1 obiektywne posunięcia przyniosły załagodzenie tumultów wywołanych sporami wóród chrześcijan. Ursyna wypędzono $i$ nastał upragniony przez rzymskich obywateli całkowity spokój. Dzięki temu rosła sława tego wybitnego zwierzchnika, zwłaszcza że podjął wiele pożytecznych deoyzj1,

występować ze świta 1 zbierać oklaski; że wszyscy mieli przede mną ustępować z drogi, jak przed jakim odyńcem, i stać szpalerem wzdłuż pochodu, albo z daleka sygnalizować, że nadchodzę" /Oratio 42,24, PG 36,488, przekład J.Szymusiaka: Grzegorz Teolog, Poznań 1965, 391/.

39 Maksencjusz, bliżej nieznany.

40 Eupraksjusz z Mauretania Caesariensis/dziś zachodnia Algeria/, kwestor, kilka razy energicznie wystąpił przeciw cesarzowi.

41 Prefekt Rzymu po ucieczce ze stolicy Wiwencjusza z powodu niemoźnośc1 zażegnania rozruchów przy wyborze papieża Damazego. Prawość jego charakteru znajduje potwierdzenie również w innych źródłach. Należał do trójki wybitnych obrońców pogaństwa, starającej się o przywrócenie ołtarza Zwycięstwa /Victoria/ w kurii 


\section{T. Zdobycie Moguncji przez Alamanón/368/}

XXVII 10, 1-2. Niemal w tym samym czasie 42 , gdy Walentynian z zachowaniem, jak mu się zdawało, ostrozności, wyruszał na wojnę, wódz Alamanów imieniem Rando ${ }^{43}$, urzeczywistniając od dawna przygotowany 1 obmyślany plan, warł się niepostrzezenie ze swymi gotowymi do grabieży lekkozbrojnymi oddziałami do ogołoconej z obrony Moguncji. A ponieważ trafił przypadkiem na obchód chrześcijańskiej uroczystości ${ }^{44}$, mógł bez trudu uprowadzić do niewoli męzczyzn 1 kobiety wszelkiego stanu 1 olbrzymie skarby, nie natrafiajac na zadną obronę 45 .

\section{U. o czuwaniach nocnych/wigiliach/}

XXVIII 6,27. Kiedy list ten /okłamujący cesarza/ doręczono na dwór cesarski $i$ przeczytano go, Meteriusz ${ }^{46}$ został na rozkaz Walentyniana aresztowany $i$ przyznał się, ze list ten napisał. W związku z tym ujęto równiez Palladiusza ${ }^{47}$. Ten zaś świadom swoich licznych zbrodni, gdy stwierdził, ze z nastaniem zmierzchu posterunek opustoszał ze strażników, którzy w święto religii chrześcijań-

rzymskiej; por. J.Wytzes, Der letzte Kampf des Heldentums in Rom, Leiden 1977, 133-148.

42 W r. 368.

43 Nieznany skądinąd.

44 Ponieważ niżej w 6 mówi o rozpoczynającej się ciepłej porze roku, chodzi tu zapewne o Wielkanoc.

45 Opisane tu wydarzenia tak wspomina św. Hieronim w liście do Ageruchii z r. 409: "Powiem nieco o obecnych nieszczęściach. Nie nasza to zasługa, ze jeszcze żjemy, 1 to nieliczni, lecz zawdzięczamy to miłosierdziu Pańskiemu. Niezliczone dzikie narody zajęły całą Galię. Przestrzeń między Alpami a Pirenejami, którą zamyka Ocean 1 ken, spustoszyli: Kwadowie, Wandalowie, Sarmaci, Alanowie, Gepidowie, Herulowie, Saksonowie, Burgundowie, Alamanowie 1 - o pożałowania godna rzeczpospolital - nasi wrogowie, Panonowie. "Ale 1 Assur przyszedł z nimi"/Ps 82,9/. Moguncja, sławne niegdyś miasto, zostało zajęte 1 zburzone, przy tym wościele zabito kilka tysięcy ludzi"/Epistola 123,15, tłum. J.Czuj, III 232/. Martyrologium Rzymskie wspomina w tej grupie zabitych bpa Aureusza i jego siostrę, Justynę /16 VI, Com. Mart.Rom. 240/.

46 0soba bliżej nieznana.

47 Trybun 1 sekretarz. Wspomniany tylko przez Ammiana. 
skiej spędzali noc w kościele 48 , zacisnąwszy sobie pętlę na szyi odebrał sobie życie.

\section{W. Polityka religijna cesarza Walentyniana I /364-375/}

XXX 9,5. A wreszcie panowanie jego zyskało tę sławę, że wśród różnorodności religii zachował neutralność, nikomu nie zakłócił spokoju i nikomu nie nakazywał wyznawać tej lub innej wiary. Nie próbowal tez przy pomocy gróźb naginać karku poddanych do swojej woli, lecz całą tę dziedzinę zachował bez zmian tak, jak ją zastał.

\section{Y. Epilog dzieła}

XXXI 16,9. Ja, niegdyś żołnierz i Grek, przedstawiłem to w miarę swych sił, zaczynając od panowania cesarza Nerwy ${ }^{49}$ aź po gwałtowną śmierć Walensa. W dziele dążyłem do przedstawienia prawdy. Nigdzie, jak sądzę, świadomie nie odważyłem się na zniekształcenie przez przemilczenie lub kłamstwo. Późniejsze wydarzenia niech opiszą sposobniejsi wiekiem 1 kwitnący nauką. Jednakze gdyby podję11 się tej pracy, doradzam im, aby ją wykonali wznioślejszym stylem.

\section{Przełożył, wstępami 1 komentarzami opatrzy 1 \\ 0 . Andrzej Bober SJ.}

48 "Qui festo die christiani ritus in ecclesia pernoctabant". Słowa "ecclesia" używa Ammian stale w sensie świątyni, budowli sakralnej.

49 Cesarz Nerwa /96-98/. Widać z tego wyraźnie, że autor powziął plan napisania dalszego ciagu "Historii" Tacyta, kończących się na panowaniu Domicjana $/+96 /$. Dzieło obejmowało 31 ksiagg. Pierwsze trzynaście za lata 96-352/ogółem więc 256 lat/zaginęły. Był to, jak widać z ilości ksiagg i lat tylko skrót dziejóm. Ocalały księgi 14-31 obejmujące lata 352-378/ogółem więc 26 lat/ 1 one sa bez watplenta najwazniejsze. Centralna figura ksiagg 15-25 jest Julian Apostata. Księgi 26-31 omawiają walki obronne Rzymian przeciw Gotom, ruchy mas ludowych w Afryce północnej, historię Armeni1 1 początek wędrówek ludów od $375 \mathrm{r}$. do bitwy $z$ Gotami pod Adrianopolem $/ 378 /$. 